\title{
LEGAL ASPECTS OF THE HYDRAULIC FRACTURING METHOD
}

\author{
MARTA DURAJ*
}

\section{INTRODUCTION}

This article is aimed at showing Polish regulations, both planned and currently in force, as well as the relevant EU law in respect of shale gas extraction. The author would like to emphasize the need to create one coherent legislative regime which would enable entrepreneurs to commence extraction by way of hydraulic fracturing without creating a danger for the environment.

\section{HYDRAULIC FRACTURING - A THREAT FOR THE ENVIRONMENT?}

In the USA, hydraulic fracturing has already been introduced as a method of gas extraction, and due to some ecological concerns scientific examinations have been carried out with a view to estimating the real threat. A recent analysis ${ }^{1}$ has shown that hydraulic fracturing may cause methane contamination of drinking water. Dissolved methane in drinking water is not currently classified as a health hazard; it is, however, an asphyxiant in enclosed spaces as well as a fire and explosion hazard. According to the aforementioned article, methane was detected in 51 of 60 examined drinkingwater wells, regardless of gas industry operations. The concentrations of methane were substantially higher closer to natural-gas wells.

There are three possible mechanisms, according to the authors of the aforementioned article, that could cause increased methane concentrations near gas wells by way of fluid migration into the shallow drinking water aquifers. The first one, and the most unlikely, is physical displacement of gas-

DOI: $10.2478 /$ wrlae-2013-0031

* LLM (Wroclaw University); marta.duraj@poczta.fm

${ }^{1}$ Stephen G Osborn, Avner Vengosh, Nathaniel R Warner, Robert B Jackson, 'Methane contamination of drinking water accompanying gas-well drilling and hydraulic fracturing' (2011) 108 (20) PNAS <http://www.pnas.org/content/108/20/8172.full.pdf+html?withds=yes $>$ accessed 11 January 2012. 
rich deep solutions from the target formation. The second is leaky gas-well casings, which would collect methane passing laterally and vertically through the fracture system. The last is connected with the possibility that hydraulic fracturing generates new fractures or enlarges existing ones above the target formation.

Another source of shallow groundwater contamination might be the introduction of hypersaline formation brines and/or fracturing fluids, but evaluating the hydrochemistry of 68 drinking-water wells and comparing them to the historical data of 124 wells in the Catskill and Lockhaven aquifers brought no evidence of such contamination.

In general, the results of scientific examinations do not give answers to the questions stemming from contamination threats generated by the hydraulic fracturing method. The authors of the article suggest that 'long-term monitoring of groundwater and surface methane emissions during and after extraction would clarify the extent of problems and help identify the mechanism behind them'.2

In order to understand the legal issues connected with the hydraulic fracturing method it is necessary to understand some basic technical information about the method itself. According to the materials presented by the Polish Geological Institute, National Research Institute ${ }^{3}$ the main concern with extracting shale gas is the fact that it occurs in rocks with very low permeability and, in consequence, it is necessary not only to drill a well, but also to procure a flow. The hydraulic fracturing method improves permeability, but only within an area of several dozen meters from the borehole. Consequently, the effectiveness of this method requires a dense arrangement of boreholes and a territory of 0.5 to 3 ha. Such an investment also requires proper infrastructure for heave vehicles and gas transmission, as well as reservoirs for technological fluids.

According to the presented materials, to stimulate gas flow it is necessary to drill both vertical and horizontal boreholes and to force large amounts of fluid, so as to create the fractures which enable gas to flow into the drill hole. The fracturing fluid contains some chemical substances. It may be used again to a limited extent only after partial purification, which is necessary because of the chemical analysis change of the fracturing fluids which occurs as a consequence of rocks leaching process.

The National Geological Institute presentation under discussion pointed out several potential threats that are taken into consideration while planning such an investment: noise emissions, emissions of gas and dust from the drilling facilities and from vehicles, emissions of gas in the drilling zone, drinking water and soil contamination and production of hazardous waste.

\footnotetext{
2 ibid.

${ }^{3}$ Monika Konieczyńska, Małgorzata Woźnicka, 'Środowiskowe aspekty wydobycia gazu łupkowego' (2011) Polish Geological Institute <http://www.pgi.gov.pl/pl/dokumentyin/doc download/172-prezentacja-konieczyskaawonicka-geologia-2011.> accessed 20 August 2011.
} 
On the other hand, the authors seem to represent the opinion that proper legal regulations, technologies providing safe methods of extraction and environmental monitoring can prevent pollution ${ }^{4}$.

For the reasons mentioned above, it is necessary to create proper legal regulations that would not stop the development of this new extraction technology and, at the same time, would ensure that the hydraulic fracturing method is used safely and would not lead to an ecological disaster.

\section{NATURAL GAS EXTRACTION IN THE EU}

The lack of relevant regulations relating to the shale gas extraction method was also pointed out in the report 'Impact of shale gas and shale oil extraction on the environment and on human health' requested by the European Parliament's Committee on Environment, Public Health and Food Safety ${ }^{5}$.

The report stated that there is a need to create a comprehensive regulation which would regulate all the issues concerned. Not only should the Environmental Impact Assessments threshold be modified, but also it seems to be necessary to make changes to the Water Framework Directive ${ }^{6}$ and the framework of a Life Cycle Analysis as based on Directive 2009/31/EC ${ }^{7}$. It should be also decided whether the use of toxic chemicals for injection should be banned in general, and if not, all chemicals should be disclosed publicly, the number of allowed chemicals should be restricted, their use should be monitored and statistics about injected quantities and number of projects should be collected at the European level along with statistics on accidents and complaints. In addition, regional authorities should be empowered to take decisions on permission for using hydraulic fracturing, and when such permission is granted it should be mandatory to monitor surface water flows and air emissions. Although there are four Directives related to mining at EU level there is no comprehensive mining framework Directive, which seems to be the most substantial problem.

In the opinion of the quoted authors (S. Lechtenboehmer et al.), the potential benefits from shale gas extraction do not compensate for the environmental risks and burdens, because of the fact that the specific gas production is very low.

\footnotetext{
4 ibid.

${ }^{5}$ Stefan Lechtenboehmer, Matthias Altmann, Sofia Capito, Zsolt Matra, Werner Weindorf, Werner Zittel, 'Impacts of shale gas and shale oil extraction on the environment and on human Heath- Report' (2011) Energy Bulletin $<$ http://www.energybulletin.net/stories/201107-25/impacts-shale-gas-and-shale-oil-extraction-environment-and-human-heath-report $>$ accessed 20 August 2011.

${ }^{6}$ Directive 2000/60/EC of the European Parliament and of the Council of 23 October 2000 establishing a framework for Community action in the field of water policy, OJ L327/1.

${ }^{7}$ Directive 2009/31/EC of the European Parliament and of the Council of 23 April 2009 on the geological storage of carbon dioxide and amending Council Directive 85/337/EEC, European Parliament and Council Directives 2000/60/EC, 2001/80/EC, 2004/35/EC, 2006/12/EC, 2008/1/EC and Regulation (EC) No 1013/2006, OJ L140/114.
} 
Although there is no one comprehensive regulation on the EU level regarding the extraction of unconventional gas, there are some regulations that are applicable. Any new regulation could be based either on Articles 191 and 192 of the Treaty on the Functioning of the European Union (TFEU) or Article 194 TFEU. The latter sets the goals of the EU within the field of energy. Articles 191 and 192 contain provisions on environmental protection $^{8}$.

Environmental issues are strongly connected with energy legislation, as clearly stated in Article 194 TFEU which declares that 'EU energy policy shall take into account the need to preserve and improve the environment'.

There are also several Secondary Law regulations which can be applicable to shale gas extraction. Legislation on permits consists of Directive 94/22/EC of the European Parliament and of the Council of 30 May 1994 on the conditions for granting and using authorizations for the prospection, exploration and production of hydrocarbons. This act imposes objective and non-discriminatory criteria based on which a permit is to be granted. Nevertheless, it is aimed at preventing Member States from imposing unjustifiably demanding conditions and does not create any system of restrictions connected with starting such activity.

The directives concerning water legislation are: Directive 2000/60/EC of the European Parliament and of the Council of 23 October 2000 establishing a framework for Community action in the field of water policy, the so-called Water Framework Directive, and Directive 2006/118/EC of the European Parliament and of the Council of 12 December 2006 on the protection of groundwater against pollution and deterioration, the so-called Groundwater Directive.

Due to the fact that fracturing fluid contains chemicals, Regulation (EC) no 1907/2006 of the European Parliament and of the Council of 18 December 2006 concerning the Registration, Evaluation, Authorization and Restriction of Chemicals (REACH) will be applicable to this method of shale gas extraction. In addition, undertakings connected with shale gas extraction would fall under the scope of the Mining Waste Directive (Directive 2006/21/EC of the European Parliament and of the Council of 15 March 2006 on the management of waste from extractive industries).

The hydraulic fracturing method, as mentioned above, involves drilling many wells and requires quite a large area, and in consequence it may influence special protection areas (SPAs) established by the Birds Directive (Directive 2009/147/EC of the European Parliament and of the Council of 30 November 2009 on the conservation of wild birds) and special areas of conservation (SACs) established by the Habitats Directive (Directive 92/43/EEC on the Conservation of natural habitats and of wild fauna and flora).

If the extraction of natural gas for commercial purposes exceeds $0.5 \mathrm{mcm}$ per day, the EIS procedure must be performed as foreseen in the EIA Directive (Council Directive 85/337/EEC of 27 June 1985 on the assessment

\footnotetext{
${ }^{8}$ Piotr Szlagowski, 'Exploitation of unconventional gas under EU law: a review of relevant legislation' in Izabela Zawisza (ed), Unconventional gas - a chance for Poland and Europe? Analysis and Recommendations (The Kosciuszko Institute 2011) 69-70.
} 
of the effects of certain public and private projects on the environment). This procedure involves providing the authorities with a detailed dossier of the project, followed by consultations with not only the relevant authorities but also with the public. A Member State may participate in the procedure if the undertaking may have significant effects on the environment in its territory. The public participation is regulated in the so-called Aarhus Convention.

Due to the lack of European regulations concerning geological and mining aspects of shale gas extraction, it is regulated by the laws of the Member States. It is also consistent with the general rule that any goals set out in the field of the EU energy policy should not affect the right of each Member State to determine the conditions for exploiting its energy resources, its choice between different energy sources and the general structure of its energy supply. In Poland, as mentioned above, there are no specific acts in this area. Consequently, the Geological and Mining Law' (the 'Act' or the 'Geological and Mining Law') is applicable.

\section{NATURAL Gas EXTRACTION IN POLAND - EXISTING REGULATIONS}

The Act distinguishes between two types of minerals, common and basic. Mineral deposits are also divided into two other groups: mineral deposits which constitute components of real estate (land) and those which do not. The former are the property of the owner of the real estate, whereas the latter belong to the State Treasury. According to the Polish judiciary (such as in the verdict of the Supreme Administrative Court date 17.04.1998, II SA 1695/97), mineral deposits which are extracted by way of the open-cast method are regarded as constituting components of the real estate. Such a conclusion is a result of the fact that extracting mineral deposits by the opencast method destroys the surface of the real estate. Article 47 of the Polish Civil Code ${ }^{10}$ states that a component is anything that cannot be separated from the thing (here: from the real estate) without damaging or substantially altering the entire thing or the separated object itself.

The above-mentioned regulation resolved a controversy which arose in the legal doctrine under the previous regulation on the ownership rights to mineral deposits ${ }^{11}$.

Natural gas is classified as a basic mineral, constituting a component of real estate, and consequently it belongs to the State Treasury.

In order to prospect for, explore and extract mineral deposits it is necessary to obtain a concession. Because of the fact that ownership of the real estate where mineral deposits have in the main been detected does not

\footnotetext{
9 The Act of 04 February 1994 Geological and Mining Law, consolidated text Journal of Laws 2005 No. 228 item 1947 (as amended).

${ }^{10}$ The Act of 23 April 1964 Civil Code, Journal of Laws 1964 No. 16 item 93 (as amended).

${ }^{11}$ Aleksander Lipiński, Ryszard Mikosz, Ustawa prawo geologiczne i górnicze. Komentarz (2nd edn, ABC 2003, LEX).
} 
belong to the enterprise willing to extract it, this makes inevitable the establishment of a mining usufruct on such a parcel ${ }^{12}$.

In addition, shale gas extraction investment would depend on a few more conditions resulting from various legal regulations, such as obtaining a decision on environmental conditions, on shore line settlement, on exemptions in areas exposed to flood hazards and water permits (based on the Water $\left.\mathrm{Act}^{13}\right)^{14}$.

Issuance of a decision on environmental conditions is required before obtaining a concession for prospecting, exploring and extracting mineral deposits ${ }^{15}$. The procedure is to be initiated by the entity willing to undertake such activity. The responsible administrative authority for investments that could impact the environment (which would include shale gas extraction) is the Regional Environmental Protection Director. The same body is obliged to decide whether the assessment of environmental conditions is necessary. In case it does, the investor is obliged to prepare a report on the influence of the undertaking on the environment, and the authority ensures the participation of the public in the procedure. On the other hand, if the investor desires to locate the investment near any 'Nature 2000' zones $^{16}$, it could be also necessary to prepare an assessment for the 'Nature 2000' regions ${ }^{17}$.

The application for obtaining decision on environmental conditions should be supported by: a report on the influence of the undertaking on the environment, an information sheet on the undertaking, a copy of a cadastral map.

Due to the fact that the hydraulic fracturing method is strongly connected with high water usage, the provisions of the Polish Water Act are also applicable. Consequently, three decisions could be taken into consideration: on shore line settlement, on exemptions in areas exposed to flood hazards and water permits.

Shore line settlement might be necessary if the planned investment requires water regulation, shaping a new bed for a watercourse or locating water facilities on grounds remaining underwater as well as on coastal grounds.

In general, according to the Polish Water Act (article 15), in the case of natural watercourses, lakes and other natural water basins, the shore edges or the line of permanent grass growth or the line settled in accordance with the average water status is regarded to be a shore line. The shore line is settled by way of an administrative decision, based on a map of demarcation of the

\footnotetext{
${ }^{12}$ Aleksander Lipiński, Ryszard Mikosz 'Gloss to article 9 of the Geological and Mining Act' in Lipiński, Mikosz (n 11).

13 The Act of 18 July 2001 Water Law, Journal of Laws 2005 No. 239 item 2019 (as amended)- hereinafter referred to as the 'Water Act'.

${ }^{14}$ Roman Rewald, Jarosław M Jankowski, 'Legal aspects of unconventional gas exploration and production projects in Poland' in Zawisza (n 8) 178.

15 The Act of 3 October 2008 on making the environmental information available and environment protection, participation of the society in environment protection and on the assessment of the influence on environment, Journal of Laws 2008 No. 199 item 1227.

${ }^{16}$ Rewald, Jankowski (n 14) 178.

17 Wojciech Radecki, Prawna ochrona przyrody w Polsce, Czechach i Stowacji. Studium prawnoporównawcze (Oficyna 2010, LEX).
} 
underwater grounds and adjacent grounds provided by the applicant. If shore line settlement is necessary in connection with locating water treatment facilities, proceedings regarding the settlement are connected with proceedings for granting a water permit for locating such buildings.

The water permits are required inter alia in cases of extraordinary usage of water or regulation and changes to the relief of the grounds adjacent to the water (article 122 of the Water Act). The first one also serves as a permit to locate appropriate water facilities.

Water permits are granted for a limited period of time; for extraordinary usage of water, however, not longer than 20 years, unless the applicant requests otherwise (article 127 of the Water Act). The water permit granted in connection with the introduction of dangerous substances into water, grounds or sewage installations is granted for a period of time not longer than 4 years. Apart from the obligatory elements of such a decision, the water permit may also contain additional obligations for the applicant, i.e. performing measurements of underground water quality.

As said above, water permits are granted upon application, which should be supported by an environmental impact statement, decisions on development and zoning conditions (if required by separate regulations) or an extract and outline from the local zoning plan (if the aforementioned decision is not required), and a description of the planned activity written in nonspecialist language (article 131 of the Water Act).

The authority may revoke or limit the permit without paying damages in situations mentioned in the Water Act, for example when the aim and scope of waters usage or requirements for executing the rights established in the permit have been changed (article 136 of the Water Act). On the other hand, the water permit may be revoked or limited against compensation if it is justified by the interests of the population, environmental protection or important commercial reasons (article 137 of the Water Act).

Polish Law has established a few restrictions concerning locating investments in zones subject to flooding. In order to locate the undertaking in such a territory, it would also be necessary to obtain the appropriate permit.

The next step would be to obtain a concession (article 15 et seq. of the Geological and Mining Law). There are two types of concession: one for prospecting and exploring of mineral deposits and a second one for extraction ${ }^{18}$. The concession is granted by the Minister of Environment, for a fixed period of time not longer than 50 years and not shorter than 3 years, as long as the entrepreneur does not request a shorter period of time. It allows the holder to conduct commercial activity in a particular area. The decision is granted to a specific entity able to guarantee that the planned activity will be conducted properly.

The procedure is initiated by filing an application with the appropriate authority (article 18 et seq. of the Geological and Mining Law). The application should contain: specification of the applicant, its registered office, address, enterprise register number, type and scope of the economic activities for which the concession shall be granted, evidence of the right to the area (space) within the boundaries of which the proposed activities are to be

\footnotetext{
${ }^{18}$ Rewald, Jankowski (n 14) 176.
} 
conducted or specification of the right that the applicant seeks to obtain, period for which the concession is to be granted and planned commencement date, specification of resources available to the applicant to ensure the proper performance of the activities.

The applicant should support the application with suitable evidence of declared facts (especially graphic annexes) and others specifying the mineral deposit. The application should therefore specify: the mineral deposits, the scale and manner of the intended mineral exploitation operation, the degree of intended utilization of the mineral deposit, including that of accompanying minerals and co-occurring useful trace elements, as well as the means enabling the achievement of this aim, the planned location of the mining area and mining protective area and their boundaries.

The applicant should also submit evidence that it has the right to use the geological documentation with the aim of applying for the concession and a deposit development plan reviewed by the competent mining supervision authority. The authority may oblige the applicant to provide further evidence and/or documents.

If the mineral deposits have already been prospected and explored, the entrepreneur may demand the establishment of a mining usufruct for himself within two years of acceptance of the geological documentation of the mineral deposits. In such a case, it is also necessary to submit the relevant application to the Minister of Environment for a concession for extracting the mineral deposits. If the entrepreneur does not use this privilege, establishing of mining usufruct becomes the subject of a tender.

The tender procedure is initiated by the respective organ ex officio or by the entity desiring to obtain the mining usufruct (article 11 of the Geological and Mining Law). The tender is regulated by the Ordinance on the tender for obtaining a mining usufruct right ${ }^{19}$. The purpose of the tender is to choose the most advantageous offer, taking into consideration the technical and financial capabilities of the tenderer, the proposed scope and technologies for performing the geological works and the proposed remuneration for granting the mining usufruct. ${ }^{20}$

It should be noted that the announcement about the tender should be made not only in the registered office of the organizer and on his website, but also in the case of natural gas in the Official Journal of the EU (paragraph 4 of the Mining Usufruct Tender Ordinance).

The regulation of the Council of Ministers dated 21 June 2005 on the tender for obtaining a mining usufruct states that only those tenderers who fulfill the requirements as defined in the specific conditions of the tender may take part in the tender process. It should be also noted that tenderers who have previously had concessions withdrawn by the appropriate authority may take part in a tender process not earlier than three years following the issuance of such a decision (paragraph 5 of the Mining Usufruct Tender Ordinance).

\footnotetext{
${ }^{19}$ Ordinance of the Cabinet of 21 June 2005 on the tender for obtaining a mining usufruct right, Journal of Laws 2005 No. 135 item 1131 (as amended) - hereinafter referred to as 'Mining Usufruct Tender Ordinance'.

${ }^{20}$ A Kowalczyk, A Szymańska, Zamówienia sektorowe. Komentarz (LEX 2011).
} 
The specific conditions of the tender (pol. SIWZ) should, in general, describe the subject of the tender, the requirements connected with the offer as well as these connected with the tenderer, information about the documents which the tenderer is obliged to provide, the objective criteria for evaluating the offers, designation of the place and terms of submitting and opening the offers (which are submitted in sealed envelopes). The template of the contract should be included as an appendix to the SIWZ (paragraph 6 of the Mining Usufruct Tender Ordinance).

The tender organizer is obliged to make the SIWZ available for the tenderer upon written request. In addition, the tenderer may pose additional questions regarding the SIWZ, to which answers are made available to and binding on all the tenderers. It is also possible to modify the SIWZ before the end of the time period fixed for submitting offers, excepting the objective criteria for evaluation of offers. In such cases, the organizer extends the time limit accordingly.

The organizer may prepare an informational brochure containing data concerning the space being the subject of the tender and the space above it (paragraph 7 of the Mining Usufruct Tender Ordinance).

On the basis such information, each of the tenderers should prepare and submit an offer, containing information about the tenderer himself and the subject of the tender, the space for which the mining usufruct is to be granted, the proposed time frame for the usufruct, remuneration, and the scope, schedule and the manner of managing the business (paragraph 9 of the Mining Usufruct Tender Ordinance).

The deadline for submitting offers must not be shorter than 90 days from the last announcement about the tender, the tender must not end later than 6 months from the end of the deadline for submitting offers. The tenderer is bound by his offer for 6 months unless the tender ends earlier (paragraph 10 of the Mining Usufruct Tender Ordinance).

The tender process ends with the conclusion of a contract with one of the tenderers. The tender organizer informs all of the participants about the result of the tender, and each of them has the right to lodge a protest within 14 days. The contract cannot be signed before the lapse of the time limit designated for submitting protests (paragraph 16 of the Mining Usufruct Tender Ordinance). ${ }^{21}$

\section{NeW LEgislation in Poland}

The new Geological and Mining Law (hereinafter referred to as the 'New Act') will enter into force on 1st January 2012, and the previous regulations will no longer be in force ${ }^{22}$.

The new law states that hydrocarbons deposits, such as natural gas, are covered by the mining ownership of the State Treasury (article 10 et seq. of the New Act). The State Treasury may dispose of its right to the mineral

\footnotetext{
${ }^{21}$ ibid.

${ }^{22}$ The Act of 09 June 2011 Geological and Mining Law, Journal of Laws 2011 No. 163 item 981.
} 
deposits by establishing a mining usufruct by way of an agreement concluded in writing. Said agreement may not be concluded for a period of time longer than 50 years. The agreement contains provisions on remuneration for a mining usufruct established on behalf of the State Treasury, which constitutes income to the State budget (article 13 of the New Act).

The establishment of the mining usufruct may be preceded by a tender procedure with the exemption of such entrepreneurs as have gained a preemption right after exploring the mineral deposits. Such a claim expires after 5 years.

It is also possible that an entrepreneur who has obtained a concession for extraction of hydrocarbons may request acquisition of the relevant real estate (article 19 of the New Act).

The new act maintains the obligation to obtain a concession for prospection and exploration as well as for extraction. The act regulates separate conditions of obtaining concessions for prospection, exploration and extraction of hydrocarbons ${ }^{23}$.

Granting a concession in such cases is always preceded by a tender procedure, unless the new act states otherwise. The act defines the criteria on the basis of which the authority selects the best offer, which are: technical and financial capabilities of the entrepreneur, proposed technology for conducting works, proposed remuneration for establishment of the mining usufruct.

The relevant authority (Minister of the Environment) grants the concession to the winner of the tender process and signs an agreement on the establishment of the mining usufruct (article 43 of the New Act). The concession authority may also grant a concession at the request of an entrepreneur. The new law also establishes a list of exceptions for areas in which the tender procedure for the concession would be excluded (article 47 of the New Act).

A new obligation is also being established by the new act, namely one under which the Minister of the Environment will be required to obtain an environmental condition decision ${ }^{24}$ as well as approvals and decisions necessary for granting a concession before opening a tender procedure. The act specifies the obligations of applicants to submit proper documentation in the tender procedure, and in addition states that the applicant would be also obliged to identify areas covered by special forms of protection, including nature protection and protection of historical monuments as well as requiring the submission of methods for preventing and remedying any adverse impact of the intended activities on the natural environment (article 24 of the New Act $)^{25}$.

The obligation to conduct tender proceedings from the mining usufruct stage to the concession stage will resolve the issue of non-

\footnotetext{
${ }^{23}$ Rewald, Jankowski (n 14) 187.

${ }^{24}$ Article 71 of the Act of 3 October 2008 on making the environmental information available and environment protection, participation of the society in environment protection and on the assessment of the influence on environment, Journal of Laws 2008 No. 199 item 1227.

25 Krzysztof Gruszecki, 'Komentarz do art.71 ustawy o udostępnianiu informacji o środowisku i jego ochronie, udziale społeczeństwa w ochronie środowiska oraz o ocenach oddziaływania na środowisko’' (LEX 2009).
} 
compatibility with Directive 94/22/EC. The Parliament intends to increase competition among entrepreneurs applying for concessions ${ }^{26}$.

The new regulations state that the Minister of the Environment may grant a concession upon request of an entity holding the pre-emption right mentioned above. There is, however, no obligation to do so.

Another important change in the new legislation is the applicability of the provisions of the Civil Code regarding leaseholds. It seems that the legislator has left more freedom to the parties to the agreement in determining the rights and obligations which arise under it. Such a situation causes certain problems, such as the legal qualification of benefits drawn and the costs incurred by the applicant from licensed activities, or the scope of applicability of leasehold law. In addition, the new law makes the applicant liable for damages caused under the Civil Law.

\section{CONCLUSIONS}

At the moment the European Union is faced with the problem of future energy resources. Nuclear energy is an important element of every discussion regarding energy supplies. On the other hand, the emerging perspective of shale gas extraction has shown that there are also other sources within the territory of the EU that could be exploited. According to recent studies, Poland has one of the largest deposits of shale gas in Europe, which could provide a chance to become independent from foreign gas suppliers.

New technologies could be a chance for a better future for Europe, but on the other hand the European legislators must not lose sight of other principles, such as environmental protection. Shale gas extraction may become a threat for the environment if it is conducted without proper technical capacities. It could be stated that new technologies require new legislation. The author has presented the technical issues connected with the hydraulic fracturing method in order to illuminate the potential threat.

In the EU there is no comprehensive legal framework for shale gas extraction. At the moment, the same situation is visible in Poland. The new act presented above is supposed to change this situation. The Polish legislator has decided that natural gas extraction requires special regulations. Nevertheless, the new law is not perfect and from the beginning gives rise to several problematic issues, such as the lack of an obligation of the Minister of the Environment to grant a concession for natural gas extraction to an entity disposing a pre-emption right.

It should be also noted that tender processes in Poland are widely criticized in conjunction with inappropriate criteria, which lead to the result that in most cases the winning tenderer is the one who presents the cheapest offer. Often the smallest amounts offered by the tenderers are not sufficient, and the planned project cannot be performed properly or even finished at all. In the case of shale gas extraction, the main criterion should be the technical capabilities and experience of the applicant. The costs should not be artificially lowered, as this may lead to an environmental disaster. In

\footnotetext{
${ }^{26}$ Rewald, Jankowski (n 14) 187.
} 
consequence, the criterion of the proposed amount of the remuneration for the mining usufruct is already alarming.

Shale gas extraction is regarded as a great opportunity for Polish business and such a chance should not be destroyed by improper legislation. Time will tell if the new regulations ensure proper protection for entrepreneurs as well as for the environment. 